\title{
THE CRYSTAL AND MOLECULAR STRUCTURE OF
} SODIUM GOLD(I) THIOSULFATE DIHYDRATE

\author{
Helena Ruben, Allan Zalkin, M. O. Faltens \\ and David H. Templeton \\ October 1970
}

AEC Contract No. W -7405 -eng -48
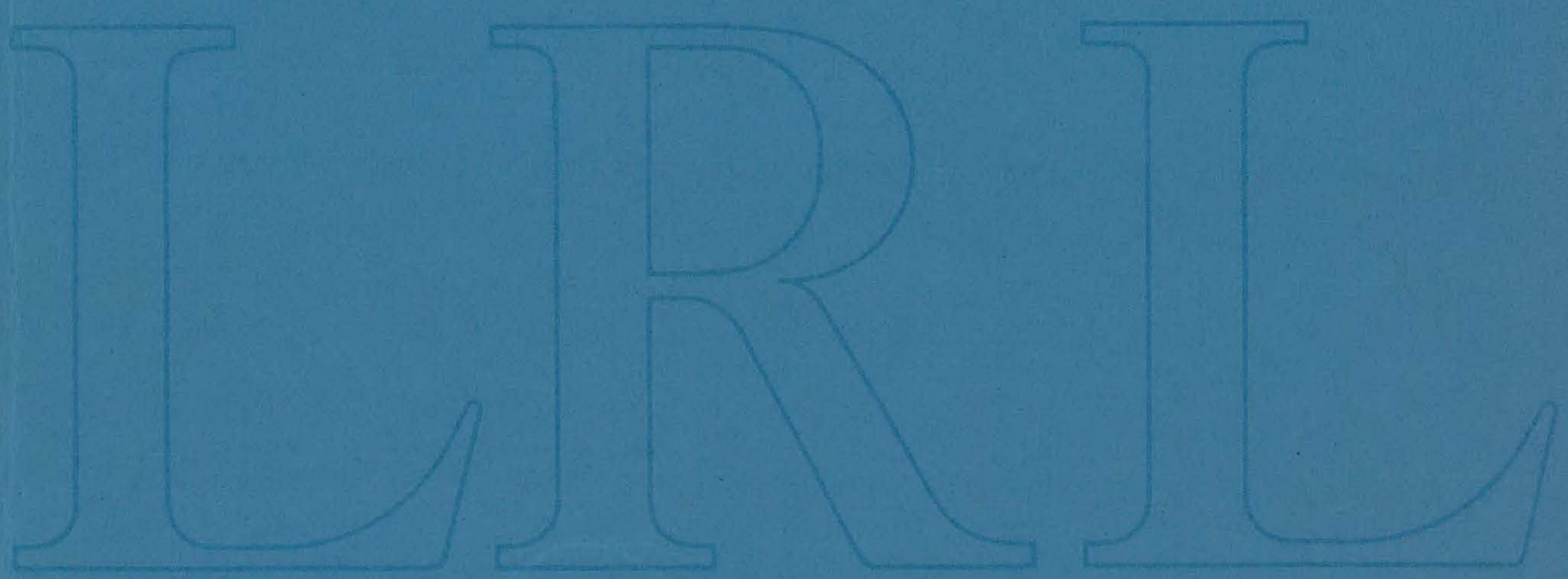

\section{LAWRENCE RADIATION LABORATORY UNIVERSITY of CALIFORNIA BERKELEY}




\section{DISCLAIMER}

This report was prepared as an account of work sponsored by an agency of the United States Government. Neither the United States Government nor any agency Thereof, nor any of their employees, makes any warranty, express or implied, or assumes any legal liability or responsibility for the accuracy, completeness, or usefulness of any information, apparatus, product, or process disclosed, or represents that its use would not infringe privately owned rights. Reference herein to any specific commercial product, process, or service by trade name, trademark, manufacturer, or otherwise does not necessarily constitute or imply its endorsement, recommendation, or favoring by the United States Government or any agency thereof. The views and opinions of authors expressed herein do not necessarily state or reflect those of the United States Government or any agency thereof. 


\section{DISCLAIMER}

Portions of this document may be illegible in electronic image products. Images are produced from the best available original document. 

CONTRIBUTION FROM THE LAWRENCE RADIATION LABORATORY AND DEPARTMENT OP CHEMISTRY, UNIVERSITY OF CALIFORNIA, BERKELEY, CALIFORNIA 94720 The Crystal and Molecular Structure of Sodium Gold(I) Thiogulfate Dihydrate ${ }^{1}$

BY heLENA RUBEN, ALLAN ZALKIN, M. 0. PALTENS, AND DAVID H. TEMPLETON

X-ray diffraction study of a aingle crystal of $\mathrm{Na}_{3} \mathrm{Au}\left(\mathrm{S}_{2} \mathrm{O}_{3}\right)_{2} \cdot 2 \mathrm{H}_{2} \mathrm{O}$ shows that it is monoclinic with $\underline{a}=18.206 \pm 0.006, \underline{b}=11.355 \pm$ $0.006, \underline{c}=5.436 \pm 0.004 \AA$ and $\underline{\beta}=97.87 \pm 0.05^{\circ}$. The space group is $\mathrm{P}_{1} / \mathrm{a}$ with four formula units per unit cell. The $\mathrm{X}$-ray density is $3.14 \mathrm{~g} / \mathrm{cm}^{3}$. The gold is located between the two thiosulfate groups in a near Iinear arrangement (S-Au-S, 176.5 $)$. The average Au-S bond distance is $2.28 \pm .01 \AA$, the S-S distance is $2.06 \pm .01 \AA$ while the $S-0$ distance is $1.46 \pm .01 \AA$. The three sodium atoms are surrounded by irregular polyhedra of oxpgen neighbors. IEGAL NOTICE

This report was prepared as an account of work sponsored by the United States Government. Neither the United States nor the United States Atomic Energy Commission, nor any of their employees, nor any of their contractors, subcontractors, or their, employees, makes any warranty, express or implied, or assumles any legal lisbility or responsibility for the accuracy, completeness or usefulness of any information, apparatus, product or process disclosed, or represents that its use would not infringe privately owned rights. 


\section{Introduetion}

One of the authors, Faltens, bad been studying aurous ( $\mathrm{Au}^{\mathrm{I}}$ ) and auric ( $A u^{I I I}$ ) compounds to elncidate their internal bonding. ${ }^{2}$ Auric and aurous compounds are textbook examples of dsp ${ }^{2}$ (square-planar) and sp (linear) hybridization respectively. Similar electric field gradients about the gold atoms might be expected as well as similar electric qualrupole splittings as observed via the Mossbauer effect. Instead the quadrapole splittings for the eurous chlnrtie wes observod to be an order of magnitude larger than that for the auric chloride. In addition to the gold halides ( $\mathrm{AuCl}$ and $\mathrm{AuCl}_{4}$ ) other gold compounds including sodium gold (I) thioavlfate dihydrate ${ }^{3}$ vere investigated, and the quadrapole splitting was observed to be consistently larger. for the aurous compounds. This crystal structure investigation of $\mathrm{Na}_{3} \mathrm{Au}\left(\mathrm{S}_{2} \mathrm{O}_{3}\right)_{2} \cdot 2 \mathrm{H}_{2} \mathrm{O}$ was undertakes to remove any doubt of 1 ts 1dentity and to establish the nature of the onvironment of the gold atom. 


\section{Experimental}

Sodium gold(I) thlosulfate 3,4 was prepared by adding 21 grams of $\mathrm{HAuCl}_{4} \cdot 4 \mathrm{H}_{2} \mathrm{O}$ to about $75 \mathrm{cc}$ of water. A $40 \%$ (by welght) solution of $\mathrm{NaOH}$ was added by drops until a vivid red-orange precipitate started to form. This solution was poured into a mechanically stirred solution of 50 grams. $\mathrm{Na}_{2}\left(\mathrm{~S}_{2} \mathrm{O}_{3}\right) \cdot 5 \mathrm{H}_{2} \mathrm{O}$ in $100 \mathrm{cc}$ of water, causing no visible change. The order of pouring is important because if the solutions are mixed in the reverse order, the black precipitate of gold sulfide results. While still stirring vigorously, 4 molal $\mathrm{HNO}_{3}$ drops were added at a rate that allowed the disappearance of any red coloration before the next drop was added. The acid was added until the redorange precipitate was dissolved and the red coloration no longer formed. This solution, approximately 200cc, was filtered through a "fine" sintered glass funnel and $800 \mathrm{cc}$ of ethyl alcohol added to the filtrate. The white flocculent precipitate which formed was collected on a similar glass funnel and washed with othanol (about 100cc) then recrystallised twice by dissolving the sodiun gold(I) thiosulfate in a minimum of water and precipitating with four volumes of ethanol. The speoimen for this study was prepared by dissolving a small amount in a minimum of water, adding two volumes of ethanol and allowing the crystals to grow overnight in the dark, as most gold compounds are photosensitive.

A clear thin crystal plato approximately $.17 \times .07 \times .02 \mathrm{~mm}$ was mounted along the $c$ axds on the ond of a thin pyrex glass fiber. A second crystal was mounted on 1ts $\underline{b}$ axis, but aince it was fractured, It was not suitable for taking data, but was useful in obtaining the 
monoclinic B angle.

The crystals were aligned on our G..E. XRD-5 hand-operated diffractometer equipped with a quarter-oircle Eulerian cradle, scintillation counter and pulse height discriminator. A molybdenum anode tube $\left(\lambda_{\mathrm{Ka} 1}=\right.$ $0.70926 \AA, \lambda_{\mathrm{Ka} 2}=0.71354 \AA$ and $\left.\lambda_{\mathrm{KK} \beta}=0.632253 \AA\right)$ operated at $45 \mathrm{kilo-}$ volts, 20 milliamperes was used. The X-rays were filtered by a $3.0 \mathrm{mil}$ sirconium filter. Coll dimensions were determined from a series of measuremexts along the noo, OKU and wel directions using peaks where the $K_{01}$, Ba2 and $K \beta X$-rays were resolved. All measurements vere made at room temperature: The intensities were measured with a take-off angle of $4^{\circ}$. 1965 independent reflections were observed and counted for ton seconds each using the stationary-crystal stationary-count technique. These are all of the data in a quarter of the sphere of reflection where $2 A<50^{\circ}$ or $\sin \theta / A<0.596$. Background was plotted as a function of $2 \theta$ and applied routinely to the reflections with the exception of a minority of intenalties where they were measured individually because of streaking from lover orders. The most intense reflection (511) was about 2303 counts per second.

The absorption parameter $\mu$ was calculated to be $145 \mathrm{~cm}^{-1}$ for MoKa X-rays. An absorption correction using the program HORSE ${ }^{5}$ was epplied to the data, and resulted in substantial improvement of the final agreement.

The standard deviation of the intensities and the structure factors vere estimated as follows. The standard deviation of the intensity, $I$, is $\sigma(I)=\left[C+B+(q I)^{2}\right]^{\frac{1}{8}}$, where $C$ is total count, 
B the background and $q$ (taken here as 0.07 ) is an arbitrary fraction of the Intensity which has been included to eccount for such nonrandom errors in the data as extinction, and the laok of stability of the electronic circuits of the instrment. The standard deriation of the structure factor, by the mothod of elnite difference, is taken as $\sigma(F)=P_{0}-\left[F_{0}^{2}-s \sigma(I) / L p\right]^{\frac{1}{2}}$. s is the scaling factor in the equation $F_{0}=\left(s I / L_{p}\right)^{\frac{1}{2}}$. For the reflections where $I \leq \sigma(I), \sigma(F)=$ $\left[s \sigma(I) / L_{p}\right]^{\frac{z}{2}}$. Lp is the Lorentz-polerization correction.

Our unpublished full-matrix least-squares program minimizes the function $R_{2}^{2}$, where $R_{2}^{2}=\Sigma_{I}(\Delta P)^{2} / L_{N} P_{n}^{2}, E_{0}$ and $\underline{F}_{c}$ are observed and calculated structure factors, and $A E$ is the difference of their magnitudes. The velghting factor $y$ is $1 / \sigma^{2}(P)$. The program accommodates both the real and imaginary parts of the dispersion correction.

Scattering factors for neutral gold, $\mathrm{Na}^{+}$, neutral sulfur and oxygen $^{6}$ were used and modifted for dispersion by adding $-2.36,0.0$, 0.1 and 0.0 electrons ${ }^{7}$ respectively. The inaginary dispersion terms were modified by adding $8.89,0.04,0.16$ and 0.0 to gold, sodium, sulfur and oxggen respectively.

Tho aniootropic temperature factar has the form $\exp \left(-\mathrm{B}_{11} \mathrm{~h}^{2}-\right.$

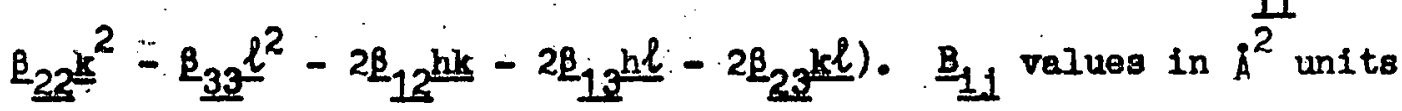
are reported for the thermal parameters: $\underline{B}_{11}=4 B_{11} / Q_{1}^{*}{ }_{i}^{*}$; where $\underline{1}^{*}$ is the 1th reciprocal cell length. 


\section{Regults}

Unit Cell and Spage Group. The space group is $\mathrm{P} 2 \mathrm{q} / \mathrm{a}\left(\mathrm{C}_{2 \mathrm{~h}}^{5}\right)$ and contains four formula units per monoolinic unit cell. The cell dimensions at $23^{\circ}$ are $\underline{\underline{a}}=18.206 \pm .006, \underline{\mathrm{b}}=11.355 \pm .006, \underline{\mathrm{a}}=5.436 \pm .004 \AA$ and $\beta=97.87 \pm .05^{\circ}$. The errore are subjectlve estimates. The volume is $1113.19 \AA^{3}$. With four formula units per unit cell, the density calculated from the $X-r a y$ data $183.14 \mathrm{~g} /$ ce which 18 to be compared wh the Iterature value of $3.09 \mathrm{~g} / \mathrm{cos} 8$

Detefmination of the Structure. The gold atom location was der . duced from a three dimensional Patterson fumction. A Fourler phased by the gold atom revealed the locations of the sodium and sulfur atoms. A least square refinement of this partial structure using isotropio temperature factors resulted in $R=\Sigma \| P_{0}|-| F_{c}|V \Sigma| P_{0} \mid=0.21$. With anisotropie thermal parametore on the gold atom the $R$ factor went to 0.19. A difference Pourier revealed the oxygen atom locations. Pinal full-matrix, all atoms anisotrople, refinement brought $B$ to 0.078 after several cycles. After making the absorption correction the final agreement was $R=0.055$.

The final results are shown in Tables I, II, and III. Tabie I Ilsts the observed and calculated stmucture factors. The final positional parumeters with thelr standard deviatlons are 11sted In Table II, where the standard deviations are estimated by the least squares procedure assming that the discrepancles represent random errore. The anisotropic thermal parameters are listed in Table III. 
Attempts at locating the bodrogen atoms were unsuccessful. The difference Fourier showed many more peaks than the four hydrogen atoms present in the structure. Attempts to refine four of the peaks that were near the water axygen atoms resulted in positions that gave unacceptable hydrogen-oxygen bond distances. The data are apparently inadequate to detect the hydrogen atoms. This is not surprising considering the big absorption correction and the presence of such a heary atom as gold.

Description of the Structure. The most significant structural feature in this compound is the $\mathrm{Au}\left(\mathrm{B}_{2} \mathrm{O}_{3}\right)_{2}^{-3}$ anion. A schematic drawing is shown in Fig. 1. The $S$ - Au - S angle is short of Inearity by about $3.5^{\circ}$. The variation of the Au $-S(3)$ and $A u-S(4)$ bond distances are less than 30, Table IV, and is not considered to be significant. The Au - S - S bond angles are somewhat imtermediate between a right and a tetrahedral angle, being somewhat closer to the latter. Each terminal sulfur aton has a tetrahedral configuration of a sulfur and three oxygen atoms and is consistent with thiosulfate in sodium thiosulfate pentahydrate. 9 The two $\mathbf{S}-\mathrm{S}$ distances in the anton are different by 3 to $4 \sigma$ from each other, but this difference is not considered by the authors to be signifioant. The average $S-0$ bond distance of all s1x such bonds is 1.458h, and no individual value is greater than one $\theta$ from this average.

The dibedral angle between the two planes defined by atoms $A u-S(3)-S(2)$ and $A u-S(4)-S(1)$ is $67^{\circ}$ (se0 Fig. 4 ).

The three sodium ions are vell encepsulated in irregular coordination spheres of oxygen atoms. $\mathrm{Na}(1)$ is coordinated by six oxggen atoms ranging in distances of 2.36 to $2.63 \AA$. Two of these 
oxygen atoms come from the two waters of hydration. $\mathrm{Na}$ (2) is also coordinated by six oxpgen atoms at distances from 2.35 to $2.54 \AA$ only one of which comes from a water of hydration. $\mathrm{Na}(3)$ is coordinated to five oxygen atoms ranging in distance from 2.34 to $2.53 \AA$, with one water of hydration involred.

Of the four hydrogen atoms only one appears to be involved in a "conventional" 0 - H......0 hydrogen bond within this sturcture; that would be the donor water oxygen $O(8)$ to $O(5)$ at a distance of $2.15 A$.

Hydrogen bonding to sulfw is not particularly a well documented effect, and if it does exist must certainly be fairly weak. Bonds of this type have been suggested ${ }^{10}$ in $S-H . \ldots S$ at $3.86 \AA$ and $N$ - H.....S at 3.35\%. In this context water $O(7)$ in this structure offers a possibility of $0-4 . . .$. s hydrogen bonding. $0(7)$ is centered in an irregular tetrabodron consisting of $\mathrm{Na}(1), \mathrm{Na}(2)$, $S(3)$, and $S(4)$. The $S(3)-0(7)-S(4)$ angle is approximately $104^{\circ}$ and the $0-S$ distances are 3.24 and $3.33 \AA$ respectively. 
TABLE I

OBSERVED AND CALCULATED STRUCTURE PACTORS FOR SODIUM GOLD(I) THIOSULFATE DIHYRATE




TABLE II

POSITIONAL PARAMETERS

\begin{tabular}{|c|c|c|c|}
\hline ATOM & $\begin{array}{c}x \\
.07361(3) \\
.0006(2) \\
.2592(2) \\
.1591(2) \\
-.0063(2) \\
.2176(3) \\
.1254(3) \\
.4129(3) \\
.0762(5) \\
-.0521(5) \\
-.0179(5) \\
.3108(5) \\
.2543(5) \\
.2783(5) \\
.1652(5) \\
.3387(5)\end{array}$ & $\begin{array}{c}Y \\
.06692(5) \\
.3396(3) \\
.0358(3) \\
-.0366(3) \\
.1713(3) \\
.3252(5) \\
-.4095(4) \\
-.1027(5) \\
.3809(8) \\
.4044(8) \\
.3425(10) \\
-.0169(9) \\
.1633(8) \\
.0010(8) \\
-.0179(9) \\
-.2627(8)\end{array}$ & $\begin{array}{c}2 \\
.1479(1) \\
.2178(5) \\
.1207(5) \\
. .0338(6) \\
.3497(6) \\
.3495(10) \\
.3159(9) \\
.2427(10) \\
.2892(17) \\
.3419(16) \\
. .0505(15) \\
-.0319(16) \\
.0916(16) \\
.3803(15) \\
.4284(19) \\
.3212(17)\end{array}$ \\
\hline
\end{tabular}

astandard deviations appear in parenthesis.

TABLE III

ANISOTROPIC THERMAL PARAMETERS ${ }^{a}$

\begin{tabular}{|c|c|c|c|c|c|c|}
\hline $\begin{array}{l}\text { ATOM } \\
\text { AU } \\
S(1) \\
S(2) \\
S(3) \\
S(4) \\
N A(1) \\
N A(2) \\
N A(3) \\
O(1) \\
O(2) \\
O(3) \\
O(4) \\
O(5) \\
O(6) \\
O(7) \\
O(8)\end{array}$ & $\begin{array}{l}811 \\
2.02(2) \\
1.82(12) \\
1.99(12) \\
2.10(13) \\
2.57(14) \\
4.33(28) \\
2.70(22) \\
2.65(23) \\
2.13(38) \\
2.53(38) \\
2.95(42) \\
2.66(40) \\
3.12(41) \\
3.20(40) \\
2.51(40) \\
4.30(50)\end{array}$ & $\begin{array}{l}822 \\
1.84(3) \\
1.71(12) \\
1.73(12) \\
2.15(14) \\
1.88(14) \\
2.62(25) \\
2.13(22) \\
2.90(24) \\
2.48(41) \\
2.29(39) \\
4.46(52) \\
3.00(42) \\
1.95(37) \\
1.92(39) \\
3.25(46) \\
2.09(40)\end{array}$ & $\begin{array}{l}833 \\
2.58(3) \\
1.41(11) \\
1.05(11) \\
2.03(13) \\
3.01(15) \\
2.47(22) \\
1.97(20) \\
2.57(23) \\
3.12(43) \\
2.71(40) \\
1.56(36) \\
2.03(37) \\
2.15(35) \\
1.52(34) \\
3.91(46) \\
2.40(39)\end{array}$ & $\begin{array}{r}812 \\
.18(2) \\
.02(10) \\
.03(10) \\
.38(11) \\
.19(11) \\
1.05(21) \\
.07(17) \\
-.25(19) \\
-.45(31) \\
.41(31) \\
.02(39) \\
.67(34) \\
-.52(32) \\
.08(31) \\
-.01(35) \\
-.034(35)\end{array}$ & $\begin{array}{r}813 \\
.31(2) \\
.15(9) \\
.14(9) \\
.11(10) \\
.93(11) \\
.19(19) \\
.19(17) \\
.30(18) \\
-.17(31) \\
.98(31) \\
-.64(30) \\
.31(30) \\
-.47(30) \\
. .21(29) \\
.85(35) \\
-.05(35)\end{array}$ & $\begin{array}{r}823 \\
-.2312 \\
.03110 \\
.0419 \\
-.52111 \\
.02112 \\
.35119 \\
-.09117 \\
-.22119 \\
.44134 \\
-.10131 \\
-.19135 \\
-.30133 \\
.40131 \\
.07129 \\
.31139 \\
-.43132\end{array}$ \\
\hline
\end{tabular}

Standard deviations appear in parenthesis. 
TABLE IV

INTERATOMIC DISTANCES ( $(\AA)$ IN SODIUM GOLD THIOSULFATE DIHYDRATE,

$\begin{array}{cccccc}\text { Atoms } & \text { Dist. } & \text { Atoms } & \text { Dist. } & \text { Atoms } & \text { Dist. } \\ \mathrm{Au}-S(3) & 2.280(3) & \mathrm{S}(4)-0(1) & 2.858(10) & \mathrm{Na}(2)-0(4) & 2.390(11) \\ \mathrm{Au}-S(4) & 2.272(3) & \mathrm{S}(4)-0(2) & 2.774(10) & \mathrm{Na}(2)-0(6) & 2.459(10) \\ S(1)-0(1) & 1.457(9) & \mathrm{S}(4)-0(3) & 2.904(10) & \mathrm{Na}(2)-0(7) & 2.348(11) \\ S(1)-0(2) & 1.458(9) & \mathrm{Na}(1)-0(1) & 2.626(10) & \mathrm{Na}(3)-0(1) & 2.532(11) \\ S(1)-0(3) & 1.451(9) & \mathrm{Na}(1)-0(4) & 2.494(11) & \mathrm{Na}(3)-0(2) & 2.381(11) \\ S(1)-S(4) & 2.051(5) & \mathrm{Na}(1)-0(5) & 2.460(11) & \mathrm{Na}(3)-0(3) & 2.383(11) \\ S(2)-0(4) & 1.463(9) & \mathrm{Na}(1)-0(6) & 2.473(10) & \mathrm{Na}(3)-0(4) & 2.423(10) \\ S(2)-0(5) & 1.458(9) & \mathrm{Na}(1)-0(7) & 2.355(11) & \mathrm{Na}(3)-0(8) & 2.338(11) \\ S(2)-0(6) & 1.461(9) & \mathrm{Na}(1)-0(8) & 2.399(11) & 0(1)-0(4) & 2.885(12) \\ S(2)-S(3) & 2.069(5) & \mathrm{Na}(2)-0(1) & 2.540(10) & 0(1)-0(8) & 2.940(12) \\ S(3)-0(4) & 2.770(10) & \mathrm{Na}(2)-0(2) & 2.433(10) & 0(2)-0(8) & 2.940(12) \\ S(3)-0(5) & 2.881(9) & \mathrm{Na}(2)-0(3) & 2.392(10) & 0(5)-0(8) & 2.751(12) \\ S(3)-0(6) & 2.936(9) & (12 & & \end{array}$

a Table contains all interatomic distances $3.00 \AA$ or less. $\underline{b}_{\text {Estimated standard deviations are indicated in parentheses. }}$ 
SELECTED ANGLES IN SODIUM GOLD THIOSULPATE DIHYDRATER

\begin{tabular}{|c|c|c|c|c|}
\hline$s(3)$ & $-A u-S(4)$ & $176.5(2)$ & $O(2)-\mathrm{Na}(2)-O(3)$ & $88.0(4$ \\
\hline $0(1)$ & $-s(1)-0(2)$ & $112.0(7)$ & $O(2)-\mathrm{Na}(2)-O(4)$ & 150.7( \\
\hline$O(1)$ & $-s(1)-0(3)$ & $109.9(7)$ & $0(3)-\mathrm{Na}(2)-0(6)$ & 170.6 \\
\hline $0(2)$ & $-S(1)-0(3)$ & $112.3(7)$ & $\mathrm{O}(4)-\mathrm{Na}(2)-\mathrm{O}(6)$ & 81.8 \\
\hline $0(4)$ & $-S(2)-0(5)$ & $112.2(7)$ & $O(4)-\mathrm{Na}(2)-O(7)$ & 118.81 \\
\hline $0(4)$ & $-s(2)-0(6)$ & $110.5(7)$ & $\mathrm{O}(6)-\mathrm{Na}(2)-\mathrm{O}(7)$ & 92.4( \\
\hline $0(5)$ & $-s(2)-0(6)$ & $112.1(7)$ & $O(1)-\mathrm{Na}(3)-O(2)$ & 82.01 \\
\hline & $-s(3)-s(2)$ & $103.6(1)$ & $O(1)-\mathrm{Na}(3)-\mathrm{O}(3)$ & 117.7( \\
\hline & $-s(4)-s(1)$ & $104 \cdot 1(1)$ & $\mathrm{O}(1)-\mathrm{Na}(3)-\mathrm{O}(4)$ & 126.6( \\
\hline $0(1)$ & $-\mathbb{N a}(1)-O(4)$ & $68.5(3)$ & $O(1)-\mathrm{Na}(3)-O(8)$ & 74.11 \\
\hline $0(1)$ & $-\mathrm{Na}(1)-0(5)$ & $116.6(4)$ & $\mathrm{O}(2)-\mathrm{Na}(3)-\mathrm{O}(8)$ & 146.8( \\
\hline$o(1)$ & $-\mathrm{Na}(1)-0(6)$ & $80.2(4)$ & $O(3)-N a(3)-O(8)$ & 113.34 \\
\hline $\bar{o}(\overline{1})$. & $-\mathrm{Na}(1)-O(7)$ & $i 56.6(5)$ & $s(3)-0(7)-s(4)$ & 103.91 \\
\hline$o(1)$ & $-\operatorname{Me}(1)-0(8)$ & $77.5(4)$ & $\mathrm{S}(3)-O(7)-\mathrm{Na}(1)$ & 101.41 \\
\hline $0(4)$ & $-\mathrm{Na}(1)-0(6)$ & $79.5(4)$ & $S(3)-O(7)-\mathrm{Na}(2)$ & 114.21 \\
\hline $0(5)$ & $-\mathrm{Na}(1)-0(7)$ & $80.7(4)$ & $S(4)-O(7)-\mathrm{Na}(1)$ & 123.6( \\
\hline $0(5)$ & $-\mathrm{Ng}(1)-0(8)$ & $107.0(4)$ & $S(4)=O(7)-\mathrm{Na}(2)$ & 89.41 \\
\hline $0(7)$ & $-\mathrm{Na}(1)-\mathrm{O}(8)$ & $88.9(4)$ & $\mathrm{Ha}(1)-\mathrm{O}(7)-\mathrm{Na}(2)$ & 123.51 \\
\hline $0(1)$ & $-\mathrm{Na}(2)-\mathrm{O}(2)$ & $80.8(4)$ & $\mathrm{Na}(1)-\mathrm{O}(8)-\mathrm{Na}(3)$ & 97.41 \\
\hline$o(1)$ & $-\mathrm{Ne}(2)-\mathrm{O}(3)$ & $90.6(4)$ & $\mathrm{Na}(1)-0(8)-0(5)$ & 117.2( \\
\hline $0(1)$ & $-\mathrm{Na}(2)-\mathrm{O}(7)$ & $167.7(5)$ & $\mathrm{Na}(3)-\mathrm{O}(8)-\mathrm{O}(5)$ & 113.2 \\
\hline
\end{tabular}

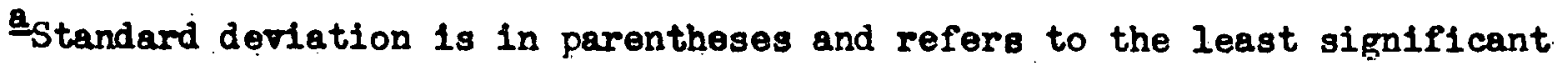
digit. 


\section{References}

(1) Research performed under the auspices of the U. S. Atomic Energy Commission.

(2) M. 0. Faltens, Mossbauer Resonance Studies of Go.ld Compounds, PhD Thesis, UCRL 18706.

(3) Gold sodium thiosulfate, long know clinically as Sanocrycin, has been and is presently being used in some medical circles for the treatment of illnesses including arthritis, tuberculosis and leprosy.

(4) H. Brown, J. Am. Chem. Soc. 49 (1927) 958.

(5) Walter C. Hamilton, private communication.

(6) D. T. Cromer and J. T. Waber, Acta Cryst. 18, 10L (1965)

(7) D. T. Cromer, Acta Cryst. 18, 17 (1965)

(8) Handbook of Chem. And Phys., 45th ed., R. C. Weast, Ed., The Chemical Rubber Co.. Cleveland; Ohio, B225.

(9) P. G. Taylor, C. A. Beevers, Acta Cryst. 2, 341 (1952)

(10) "Hydrogen Bonding in Solids", W. C. Hamilton and J. A. Ibers, W. A. Benjamin Inc., New York, 1968, p167. 


\section{Figure Captions}

Fig. 1 Schematic drawing of $\mathrm{Au}\left(\mathrm{S}_{2} \mathrm{O}_{3}\right)_{2}^{-3}$ anion.

Fig. 2 Molecular packing in the unit cell of Sodium Gold(I) Thiosulfate Dihydrate.

Fif:. 3 Stereo view of Sodium Gold(I) Thiosulfate Dihydrate showing examples of the bonding of the sodium atoms. 


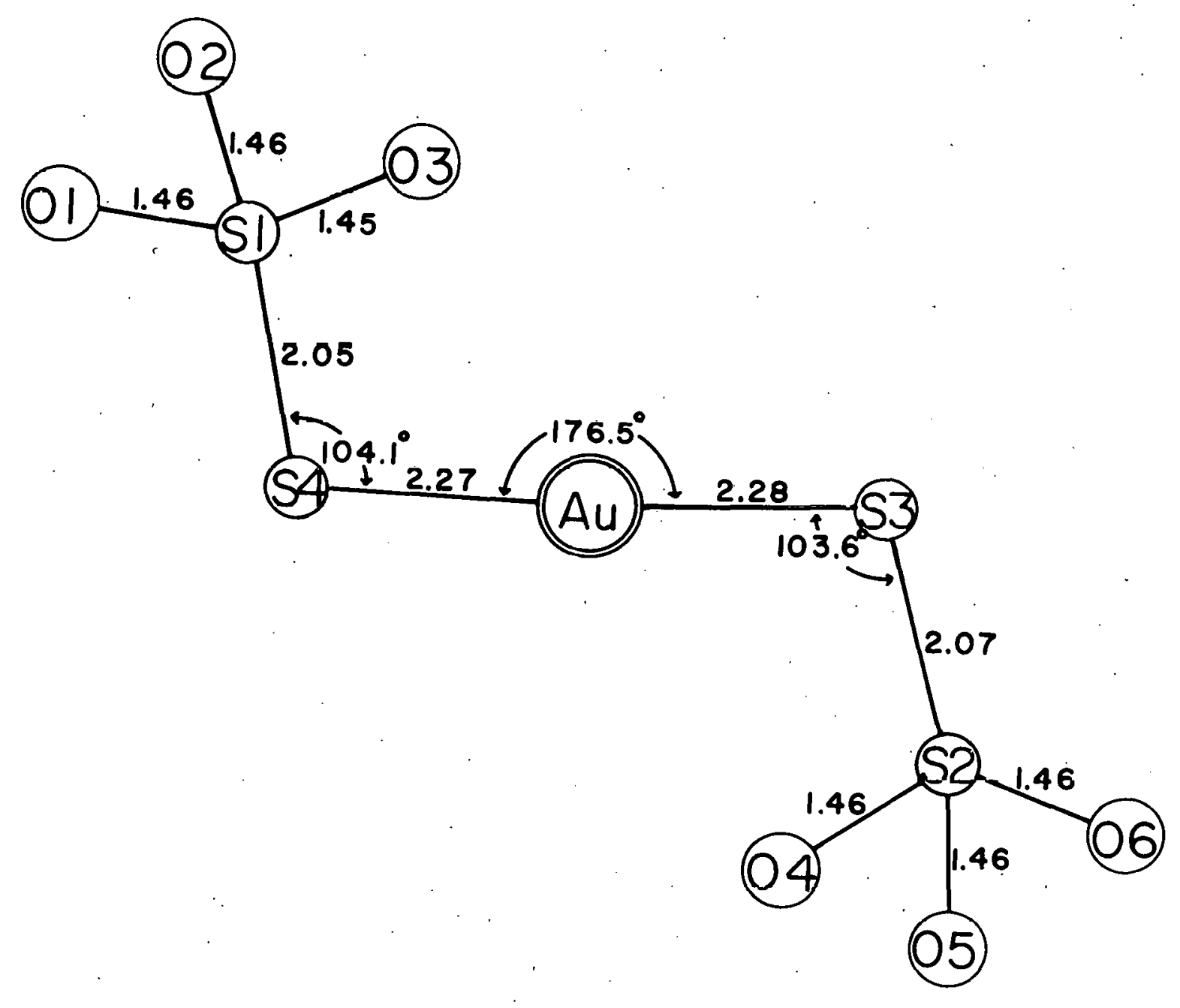

XBL 707-1307

Fig. 1 


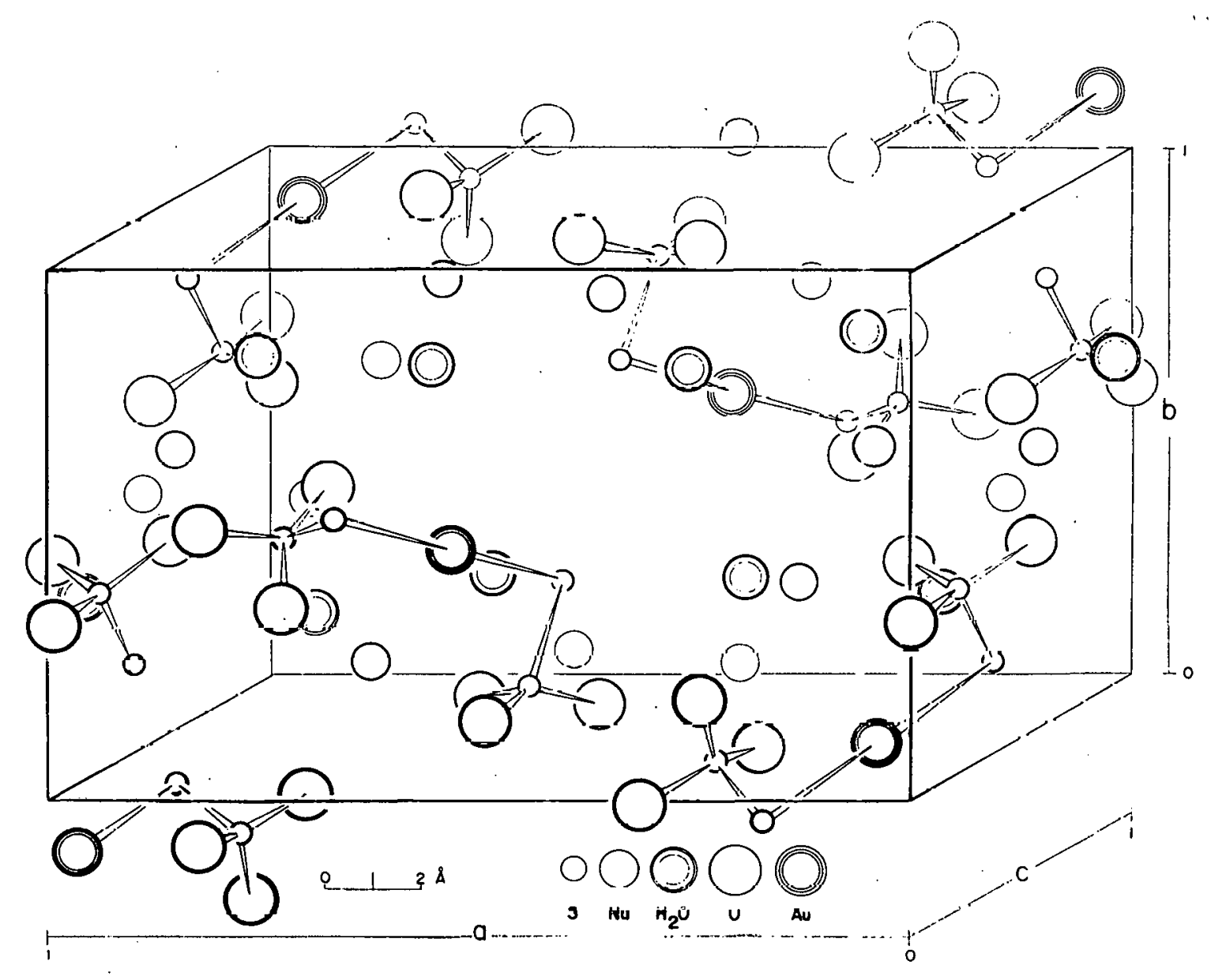

inive-1123s 
0
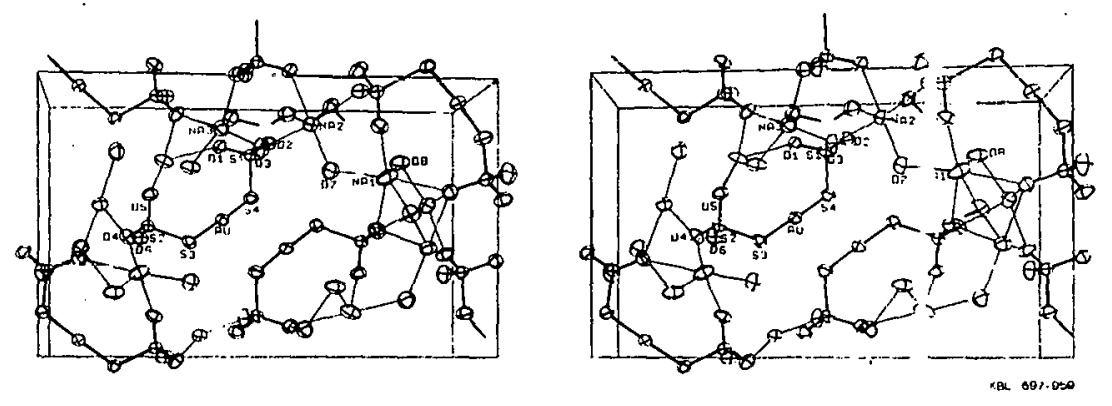

Fig. 3 . 


\section{LEGAL NOTICE}

This report was prepared as an account of Government sponsored work. Neither the United States, nor the Commission, nor any person acting on behalf of the Commission:

A. Makes any warranty or representation, expressed or implied, with respect to the accuracy, completeness, or usefulness of the information contained in this report, or that the use of any information, apparatus, method, or process disclosed in this report may not infringe privately owned rights; or

B. Assumes any liabilities with respect to the use of, or for damages resulting from the use of any information, apparatus, method, or process disclosed in this report.

As used in the above, "person acting on behalf of the Commission" includes any employee or contractor of the Commission, or employee of such contractor, to the extent that such employee or contractor of the Commission, or employee of such contractor prepares, disseminates, or provides access to, any information pursuant to his employment or contract with the Commission, or his employment with such contractor. 
